\title{
Lecturers' Perception on English Ability Towards the Lecturers' Professionalism
}

\author{
Rini Afriani ${ }^{1 *}$ \\ ${ }^{1}$ Universitas Putra Indonesia “YPTK”, Padang, Sumatra Barat, Indonesia \\ ${ }^{*}$ Corresponding author. Email: riniafriani007@gmail.com
}

\begin{abstract}
Lecturers need English to develop their professionalism. English can be a bridge in helping their professional career. In this situation, lecturers should have a good English ability to reach their target. This descriptive study aims to describe the perceptions of lecturers about their English ability. The data were obtained from the questionnaires filled by lecturers in Padang and the interviews. The results indicated that the lecturers' perception towards their professionalism were $35.7 \%$ stated strongly agree, $45.9 \%$ stated agree, $9.6 \%$ stated neutral, $6.6 \%$ stated disagree and $2.2 \%$ stated very disagree. The interview results revealed that good English abilities made them easier in getting certification, getting information, continuing their study, and getting scholarships.
\end{abstract}

Keywords: Perception, English Ability, Professionalism

\section{INTRODUCTION}

Lecturers have an important role in the university environment because lecturers are one of the main needs as a driving force in matters related to the scientific and academic activities. This situation makes lecturers should be active in responding to the needs associated with the development of academic activities. One of the basic needs for all majors today is the acquisition of a foreign language like English. As a lingua franca, English becomes a media for studying and expanding knowledge.

In improving the knowledge, lecturers must have strong motivation and a dynamic special knowledge and skills. All aspects in advancing the career of the lecturers are inseparable from the use of English, both in the form of special skills obtained through education and forms of community service that require extensive literature as a comparison to improve the quality of service oriented to social services

Lecturers' profession is related to three aspects, those are professional ability, social ability and personal ability[1]. Related to these aspects, a professional development is the process of maintaining the quality and relevance of professional services throughout the course of work. Lecturers must be active in various activities as a member of professional organizations. Lecturers are also required to have a professional code of ethics that has strength and status as an expert that can be accepted by the society. The values obtained should be applied in an appropriate way so that a professional are stated that a person acts based on a relevant field of knowledge, has a stable and independent personality, does not violate laws, social and religious norms.

Talking about the lecturers' professionalism is also related to the lecturer highly skilled and competent in strengthening their teaching profession[2]. Lecturers will have a good skill and competent if they have more reference and knowledge in their discipline. It has a relation to their ability in communicating to deliver and getting the knowledge. One way that can be done is by having the ability in English as a lingua franca to improve and expand their knowledge.

In getting their professional status like getting certification from the government, lecturers must complete some procedures. The aspects that include in the procedures still have a relationship with the lecturers' ability in English. They need to have a certificate of English proficiency to show their ability in English as a foreign language in Indonesia. If lecturers can get a good score in TOEP, it can help them easier to go on to the next step in some procedures of the certification process. A lecturer that has passed the procedures in getting certification has one requirement to be a professional lecturer[3].

Professionalism is also related to the lecturers' ability in making a decision for practicing and having a higher education literature[4]. The development of learning ways through technology should be a big chance for the lecturers to increase their English knowledge. In order to complete their professional career in producing more scientific research, lecturers 
also need to have good writing ability. Many kinds of virtual writing courses are available[5]. Those are available with a clear instruction and a formative feedback that can improve learners' writing ability. Thus, the process depends on the lecturers themselves, do they want to take the chance or not. Next, automated written corrective feedback (AWCF) is a system that can motivate learners to write and revise their papers[6]. This way can increase lecturers' confidence and ability in writing academic articles.

Trying to take more test in English can be the good way to know their progress in English. English online test in language testing can make an efficient and accessible test [7]. There is no reason to say that lecturers have no time to join a test. There are many kinds of online test that can be a tryout for the lecturers to advance their English ability. When lecturers can show their professional development by taking all opportunities, it can be a motivation to the people around them. Lecturers should be a model of a change to show their commitment in expanding their professional career[8].

One way to expand the professionalism was by raising the lecturers' competence[9]. This article was focused on the lecturers' perception on their professional competence in English ability. As a lingua franca, English has accomplished the need for communicating[10]. Related to this phenomenon, English ability becomes an important part in developing the lecturers' professionalism. This article described about the lecturers' perception and reasons on English ability toward the lecturers' professionalism in their professional career.

\section{METHOD}

This research used descriptive method. The data were obtained from questionnaire, interview and recording. A Likert scale questionnaire was used as a data collection tool. Then, a trial was conducted to 30 lecturers in getting out the validity and reliability of this research. In getting the data, the researcher distributed the questionnaires to 95 lecturers who came from 5 universities in Padang that based on the number of the lecturers in each university. Next, 10 lecturers were chosen and interviewed as participants in collecting the data. To find the data, the researcher transcribed the results that were found from the interview and determined the appropriate reasons related to the research questions.

\section{RESULTS AND DISCUSSION}

There were two main points that were explained in this article. There were the lecturers' perception in using

English toward their professionalism and the lecturers' reasons had those perceptions.

\subsection{Lecturer's perception in using English toward their professionalism}

The percentage of the lecturers' perception on English ability toward their professionalism can be seen in table 1.

Table 1 the Percentage of the Lecturers' Perception

\begin{tabular}{|cc|c|c|c|c|}
\hline & & Frequency & Percent & $\begin{array}{c}\text { Valid } \\
\text { Percent }\end{array}$ & $\begin{array}{c}\text { Cumulativ } \\
\text { e Percent }\end{array}$ \\
\hline Valid & 1 & 17 & 2.2 & 2.2 & 2.2 \\
& 2 & 50 & 6.6 & 6.6 & 8.8 \\
& 3 & 73 & 9.6 & 9.6 & 18.4 \\
& 4 & 349 & 45.9 & 45.9 & 64.3 \\
& 5 & 271 & 35.7 & 35.7 & 100.0 \\
& & & \\
Total & 760 & 100.0 & 100.0 & \\
\hline
\end{tabular}

Based on the result of the research in table 1 , it can be seen that the scales of frequency of the lecturers' perception were strongly agree, agree, neutral, disagree, and very disagree. Then, the lowest percentage from the table was $2.2 \%$ stated very disagree. The highest one was $45.9 \%$ stated agree.

The result of the lecturers' perception on English ability toward their professional career can also be seen in Figure 1. The lowest frequency of the answer was $2.2 \%$ with the lowest frequency 17 stated very disagree. Then, the highest one was $45.9 \%$ with the highest frequency 349 with standard deviation 0.95 . From the percentages that have gotten, it can be summarized that the lecturers' perception about English through their professional career were good because English ability may help their needs in completing the rules to be professional lecturers.

Histogram

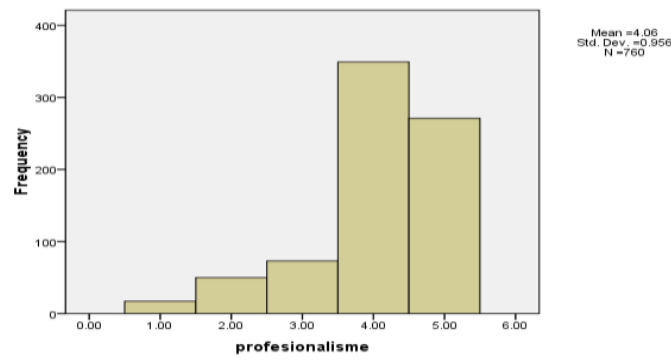

Figure 1 Frequency of the Lecturers' perception toward lecturers' professionalism 


\subsection{The lecturers' reasons had those perceptions}

Based on the data obtained, there were several reasons the lecturers stated agree that good English skills can increase their professionalism as a lecturer. The first reason was English made them easier to fulfil the needs related to completeness of the certification's requirement such as TOEP. If they had good English ability, lecturers believed that they could pass the test once, however some lecturers needed to take TOEP more than once or many times. This situation took more energy, time and money. It was because they should pay more for the test. Then, the lecturers needed to prepare themselves to pass the score as the requirement to achieve the certification. Based on the interview, some of them said that they had more than four times got the test and the results were still insufficient. Thus, they tried to learn English more in order to get the score that they needed.

The second reason was English made easier to obtain the information related to further studies. There were many information related to Doctoral programs especially if the lecturers wanted to study abroad. It could be like obtaining desired information from the university and determining the right university destination. Then, finding the information about supervisors that had the same research background with the proposal proposed also needed English skills in communicating. The lecturers said that their English ability determined the level of their understanding in reading the information. If they had wrong comprehension about what they read, it became a problem for them. They felt afraid to make a mistake because of lack of English ability.

The third reason was English helped the lecturers in making a choice to continue their study. After getting information about the university that was suitable with their research target, lecturers also said that they needed to have good understanding about all information and rules that were available there, in this situation good English ability will be helpful for them. Lecturers should have productive and receptive English skills to complete their doctoral program[11].

English ability actually is not only important in making a choice for the university target, but also in facing the doctoral journey. Based on the interview, the lecturers said that they needed to study hard to increase their English ability, because they needed to have the ability to communicate in spoken and also in written language. Moreover, their ability to read and getting more references in English were important to support the learning during doctoral program. Some of the lecturers said that they had tried to practice and improve their English proficiency by making research articles and joining some international conferences.
Fourth, lecturers also stated that good English ability helped them to obtain scholarships. It was started from obtaining information about the scholarships and the scholarship' requirements. They said that to get a scholarship, they had to follow some procedures and completed the requirements needed. Most of the steps that should be followed used English as an instruction. In this situation, some lecturers said that they really wanted to improve their English because they did not want English became an obstacle to catch their purpose as a professional lecturer. Thus, the good English ability would help them a lot to complete each step. Then, lecturers also said that they needed to have the ability to write and create an appropriate email in English as the process in getting the scholarship. Lecturers believed that they needed to have the ability to follow the phases in order to acquire the good result.

Lecturers have perception that English took an important part in the learning process and their professional career. Having good English skills were an added value for lecturers with non-English majors. It was because they can explore their disciplines by using English to increase their professionalism.

In this article, based on the percentage of the highest score who stated agree $45.9 \%$, it could be seen the lectures' perception and the reasons toward English ability to their professionalism. Therefore, the researcher found some reasons from the lecturers related to their perception in improving their professional career such as continuing their study and getting scholarship. These findings had the similarity with the finding from Trinova about lecturers' professionalism development that includes education, research, and community services[12]. The findings of professionalism were related to the lecturers' effort in pursuing doctoral education and their activities in joining some international conferences. It was also related to the research finding that was found by Netii and Saragih that the lecturers want to continuing their study[13]. It was the way of the lecturers in increasing their professional career. The lecturers had perception that this way would be easy if they had good ability in English to support their learning activities.

\section{CONCLUSIONS}

Based on the results found in this research, it can be stated that, the lecturers had good perception about English related to their professionalism. This perception become an important thing in motivating lecturers to expand their professional career. Many aspects related to the lecturers' career has relation with their ability in English. This article described the real situations happened in the lecturers' academic context that $45.9 \%$ of the lecturers stated agree if English was important to 
their professionalism. It was only $2.2 \%$ stated disagree. The lecturers also had a good perception about the need of English in their professional career. It can be stated that there were some reasons from the lecturers, those were the need for completing certification's requirement, getting information, continuing their study and obtaining scholarship. Based on the percentage and the lecturers' reasons toward the English ability, many lecturers had good perception that English was important to their professional career. Finally, Lecturers need to learn more about English to accomplish their good career.

\section{REFERENCES}

[1] A. Sanusi, Studi Pengembangan Pendidikan Profesional Tenaga Kependidikan. Bandung: IKIP Bandung, 1991.

[2] Z. Abdullah, K. E. Hoque, N. H. Ramlan, and S. Shafee, "Designing the Structural Model of TVET Lecturers' Professionalism and Generic Skills Based on an Empirical Study in Malaysia," SAGE Open, vol. 9, no. 3, 2019, doi: $10.1177 / 2158244019861456$.

[3] K. Sonia Piscayanti, "Pengaruh Sertifikasi Dosen Terhadap Kinerja Pengajaran Dosen Undiksha," $J$. Ilmu Sos. dan Hum., vol. 4, no. 1, pp. 534-544, 2015, doi: 10.23887/jish-undiksha.v4i1.4922.

[4] F. Trede, "Role of work-integrated learning in developing professionalism and professional identity," Asia-Pacific J. Coop. Educ., vol. 13, no. 3, pp. 159-167, 2012, [Online]. Available: http://www.apjce.org/files/APJCE_13_3_159_167. pdf.

[5] L. Aull, "Student-centered assessment and online writing feedback: Technology in a time of crisis," Assess. Writ., vol. 46, no. September, 2020, doi: 10.1016/j.asw.2020.100483.

[6] S. Koltovskaia, "Student engagement with automated written corrective feedback (AWCF) provided by Grammarly: A multiple case study," Assess. Writ., vol. 2, no. 4, 2020, doi: 10.1016/j.asw.2020.100450.

[7] T. Brunfaut, L. Harding, and A. O. Batty, "Going online: The effect of mode of delivery on performances and perceptions on an English L2 writing test suite," Assess. Writ., vol. 36, no. September 2017, pp. 3-18, 2018, doi: 10.1016/j.asw.2018.02.003.

[8] E. Triyono, "Pelaksanaan tridharma perguruan tinggi sebagai pengembangan profesional dosen politeknik," Semin. Nas. Terap. Ris. Inov., vol. 53, no. 9, pp. 1689-1699, 2013.

[9] L. P. Sinambela, "Profesionalisme Dosen Dan Kualitas Pendidikan Tinggi," J. Popul., vol. 2, no. 4, pp. 579-596, 2017.

[10] B. Labrador and N. Ramón, "Building a secondlanguage writing aid for specific purposes: Promotional cheese descriptions," English Specif. Purp., vol. 60, pp. 40-52, 2020, doi: 10.1016/j.esp.2020.03.003.

[11] Usada, "penghambat kemampuan berbahasa inggris dosen," Paedagogia, vol. 11, no. 1, pp. 41-50, 2008

[12] Z. Trinova and M. Kustati, 'Lecturers' Professionalism: Reflective Experiences among Islamic State Universities in West Sumatera," Tadris J. Kegur. dan Ilmu Tarb., vol. 4, no. 1, pp. 63-75, 2019, doi: 10.24042/tadris.v4i1.4117.

[13] Netti and A. M. Saragih, "Pengaruh Tingkat Pendidikan Dosen Terhadap Kinerja Dosen Politeknik Negeri Medan," 2017. 